\title{
Communication and Resource Conflict Resolution: The Case of Aguleri-Kogi Feud Over Ownership of Crude Oil Finds
}

\author{
Allen Nnanwuba Adum \\ Department of Mass Communication, \\ Nnamdi Azikiwe University, Awka, \\ Anambra State, Nigeria \\ Ogochukwu Ekwenchi \\ Department of Mass Communication, \\ Nnamdi Azikiwe University, Awka, \\ Anambra State, Nigeria \\ Emeka Odogwu \\ Department of Mass Communication, \\ Nnamdi Azikiwe University, Awka, \\ Anambra State, Nigeria \\ Kobimdi Umeh \\ Department of Mass Communication, \\ Nnamdi Azikiwe University, Awka, \\ Anambra State, Nigeria
}

\begin{abstract}
Conflict is inevitable among communities especially where there are vested interests or contentious boundaries. This paper analyzed the role and effect of communication in conflict resolution within community setting. The controversy investigated was Aguleri-Kogi Crude Oil ownership feud otherwise known as "Crude oil War", which had led to loss of many lives and property in both communities. Using literature review methodology, which borders on conflict and conflict resolution; effects of communication in conflict prevention and resolution; historical account of Anambra River Basin Communities; and, efforts of stakeholders in the various communities towards resolution of the resource conflict, it was observed that conflict can be either good or bad, depending on the way it is handled; that poor communication escalates conflict; and, that effective communication, anchored on dialogue and negotiation, is the key to conflict resolution. We observed that both parties in Aguleri-Kogi feud relied more on litigations in settling their resource dispute which has lingered for a long time. This paper, therefore, suggested among other things, the need for the stakeholders in conflicts to embrace negotiation and dialogue in the resolution of differences.
\end{abstract}

Keywords: Aguleri-Kogi feud, Anambra River Basin, Crude oil ownership, Resource conflict

DOI: $10.7176 / \mathrm{JRDM} / 56-06$

Publication date:June $30^{\text {th }} 2019$

\section{Introduction}

Conflict is now one of the realities of our present human existence because it is highly impossible for people to interact without disagreement of one form or the other. Experience has shown that relationship between communication and conflict and its resolution is double-edged. This is so because most conflicts occur as a result of misinformation or disinformation and cannot be resolved without effective application of communication. Ideally, therefore, the communication roll in resolving conflict is to find out ways of minimizing the negative aspect of conflict and maximizing the advantages of the functional aspects in settling parties involved in a 
conflict. The good or bad effect of conflict depends on communication techniques and its applicability by parties' involved or external mediator. Arguably, improper handling of conflict can lead to loss of life, property, low productivity and retarded socio-economic growth, while proper handling can lead to freedom, reduction of tension and stress, high production and so on. It is natural that people's view, opinion and actions must differ.

The major concern of this paper is to buttress how communication can be used in resolving Aguleri- Odeke Kogi Crude Oil ownership feud.

The world is experiencing numerous tension and anxious moments because a lot of people ignorantly believe that it is better to suppress conflict than resolving it. This unfortunately has led to a lot of scheming on the part of the political leaders and others to either deny or ignore the opposing view. Obviously, the frustration and anger bottled up as a result of this does more damage than the initial conflict when it finally explodes. There is no denying the fact that, initially the parties to a conflict may appear incompatible but through the process of negotiations and bargaining the parties learn more about each other and create room for compatibility. This is the idea of conflict resolution through communication.

Efficient application of communication in resolving conflict depends on the proper understanding of the dynamics of conflict and the manner of communication. This paper therefore, seeks to review communication strategies among the stakeholders towards resolving the age-long conflict between Aguleri-Odeke Kogi communities over the ownership of Anambra Basin Crude Oil.

\section{The Concept of Conflict}

In basic terms conflict can be seen as the clash, disagreement between hostile and opposing elements, ideas, forces or even communities. Coser (1956) cited in Aslam (2014) defines conflict as struggle over values and claims to scare status, power and resource. Kriesberg (1956) cited in Aslam (2014) regards conflict as a relationship between two or more parties who believe they have incompatible goals. This implies that for conflict to occur there must be divergent interests and views. These interests and views must have escalated so as to qualify as violent conflict. A broader definition of the concept was provided by the Heldeberg Institute for International Conflict Resolution is defined as the clash of interest (personal differences) on national values between at least two parties (organized groups, states, organizations) that are determined to pursue their interest and win their case (Hilk, 2005). One common deductive thread in these definitions is that conflict has an element of disagreement either in principle, perception, values, ideology or culture. It is also cyclic in process. It occurs and progresses in stages (Mogekwu 2011 p.241). This suggests that conflict is a central part of living with others because people often see and react to things or situations differently.

Conflict is inevitable and at times surfaces even when good is intended. This is why everyday human activities are filled with conflict. According to Aslam (2014) conflict exists in a relationship when parties believe that their aspirations cannot be achieved simultaneously or perceive a divergence on their values, needs and interests (latent conflict) and purposely employ their power in the effort to defeat, neutralized or eliminate each other to protect and further their interest in the interaction (Manifest conflict). The import of this definition is that conflict cannot come up without the element of vested interest and people engage in conflict so as to further or protect this interest. Conflict develops in stages. Brahm (2003) identified the following as five (5) stages of conflict development:

- The latent stage

- The conflict emerging stage

- The conflict escalating stage

- The dispute settlement stage, and

- Post conflict peace building stage.

This indicates that conflict does not occur as a revolution rather it undergoes gradual stages of development. Conflict is defined as a struggle over and claims to scarce status, power and resources in which the aim of the opponent is to neutralize, injure, or eliminate their rivals (Coser 1986). In this sense, conflict may be conceptualized as a way of settling problems originating from opposing interest and from the continuity of the society. Thus, Park and Burgress (1971) in Ikoro and Ukonu (2016) argue that conflict is designed to resolve divergent views and achieve some kind of unity even if it is through extermination of the conflict parties. Conflict may therefore not be regarded only in a negative light of dysfunctional or disjunctive process and breakdown of communication as some scholars tend to suggest. Conflict, arguably, is a conscious act involving 
personal or group contact and communication. Evidence to this claim is observable in activities of conflicting parties which include communication and strategic plans to thwart the opposing party.

Conflict can either be bad or good depending on how it is handled. Lych and Galtung (2010) posit that conflict is a clear opportunity for human progress, using the conflict to find new ways, being imaginative, creative, transforming conflict so that the opportunities take the upper hand without violence. This means that people in the process of tackling conflicting situations can realize a better of way doing things which might seem very difficult prior to the conflict.

Conflict can either be violent or non-violent and can result to negative or positive consequences. Its positive results can be seen in increment in productivity in organizations, resolution of impending crisis before it gets to the stage of escalation. On the other hand violent conflicts, as armed conflict, war, terrorism etc can have negative consequences such as death of the victims, migration, massing of refugees, eruption of epidemic disease, damage of infrastructural facilities and other economic and social vices. Lending credence to this Amodio \& Di Maio (2018) assert that the economic consequences of violent conflicts are devastating and stressed that it results to lower growth, lower investment and lower productivity in developing countries where the incidence of violent conflicts occur most.

Early scholars in the field of conflict and conflict resolution Fink (1968); Mack \& Snyder (1957) have identified large schemes for describing sources or typology of conflict. Similarly, Daniel Katz (1965) cited in Fisher, Ibrahim, Jawed Ludin, Smith, Williams and Williams (2000) created a typology that distinguished three distinct sources of conflict: economic source, this entails jostling or competing for a scare resource. This conflict normally emerges, as individual, parties, communities, even nation struggle to maximize gain sometimes to the detriment of others. This is where Aguleri-Kogi Crude Oil ownership feud, which form the main thrust of this paper, lies. Values sources: this has to do with incompatibility in ways of life, ideologies, principles and practices people believe in. Power sources: this emphasizes the conflict that originates from a situation where parties wish to sustain or maximize its influence in a relationship or social setting. Burgess (2007) in Ikoro and Ukonu (2016) categorized conflicts into: Communal conflicts, institutionalized conflict, domination conflict, environmental conflict (i.e physical or natural environments), community conflict, ethnic and racial conflicts, family conflicts, gender conflicts, generational conflicts, identity conflicts, role conflicts, interpersonal conflicts, intra and extra group conflicts, labour-relations, value conflicts, armed conflicts, technological conflicts, personality conflicts, intra-personal conflicts and others. This classification notwithstanding, one characteristic of conflict is the existence of divergent interest.

\section{Resource Conflict: Conceptualized}

Resource conflict otherwise known as Natural resource conflict entails disagreement or disputes over access to, control and use of natural resources. This kind of conflict often emerges because of divergence in human need and use of resources such as forest, water, pasture and land or desire to manage them in different ways.

One important characteristic of natural resources that make them attractive to human interest is that they are valuable and scarcely exist in abundant quantity. Disagreement over natural resources also arises when the needs of the users are incompatible or when priorities of the users are not considered in policies, programmes and projects. Resource conflict can also occur if there are contradictions between the local and introduced management system; misunderstanding and lack of information about policies and programme objectives; lack of clarity in laws and entitlements; inequality in resource distribution and exclusion from or inclusion of a group in the management of natural resources which is not a stakeholder (FAO 2018). This exclusion and inclusion is the major cause of Aguleri of Anambra and Odeke feud. The cause notwithstanding, resources conflict often involves many actors and divergent stakeholders. They range from local men and women, neighbouring communities mainly in the case of boundary dispute, community based organizations, business organizations, government and non-governmental bodies and so on.

Nigerian Stability and Rehabilitation Programme (NSRP 2017) shows that the underlying causes of many economic grievances in Nigeria is exclusion. The report argue further that there is widespread perception across Nigeria that the country's wealth (mainly revenue from oil and gas) are distributed based on political patronage rather than need or the best interest of the country. Following the research and consultation, NSRP identified 3 key themes that drive economic conflict in Nigeria: access to economic and employment opportunities; competition over land and water use; and environmental degradation. These conflicts are noted to affect children and women the most. 


\section{The Concept of Communication Defined}

Elements of communication include the sender who encodes the message, the receiver who decodes it, the message which is the content of the communication, the channel and noise. One of the striking features of communication, as identified, is the identification of communication as a process which means that sender and receiver must participate actively for effective communication to occur. Njoku (2017) stressed that listening and responding appropriately to the message of others (which is what conflict resolution is all about) is demanding; especially, where the source and the receiver operate from different frames of reference.

\section{Conflict Resolution}

It is a truism that to avoid further damage to nature, life and property and to ensure socio-economic growth and political stability, stakeholders in organizational or societal conflict must be placated. The parties to conflict should be made to settle their differences. The process in doing this is known as conflict resolution. Conflict resolution in its simplest term is, therefore, the method and processes that has to do with facilitating the peaceful ending of a conflict and retribution. The concept of conflict resolution is open to many interpretations. On one hand it can be regarded as any process that revolves or ends conflict via methods which can include violence or warfare. Alternatively, it can be viewed as a non-violent process that manage conflict though compromise or through the assistance of a third party who either facilitates or imposes a settlement or resolution on the parties.

This implies that instrument of conflict resolution depends on the nature and parties involved in a conflict. Conflict resolution processes are many and varied and can be seen on a continuum ranging from collaborative, participatory, informal, non-binding processes ( such as mediation, conciliation, third party negotiation) to adversarial, fact-oriented, legally binding and imposed decisions that are arise from institutions such as the courts and tribunal Boulle (1996) in Adejimola (2009). Typically, mediation, conciliation or negotiations are activities that facilitate communication between participants who are seeking to resolve their differences in a cooperative way. This approach could be better for conflict resolutions since majority of scholarly arguments on conflict management suggest a belief in the approach, as the key to the resolution of conflict is to focus on the interest of the contending parties rather their positions, which is a situation where one party seeks to impose on another. Laue and Cormick (1978) argue that conflict can only be considered resolved, if the following conditions are met:

- The solution jointly satisfies the interest and the needs of the parties via joint agreement.

- The solution does not compromise the value of either party.

- The parties do not reprediate the solution even if they have the power to do so.

- The solution is fair and just and becomes self-supporting and enforcing.

This form of conflict resolution seems ideal because it aims at achieving an enduring outcome, but it is not always practicable in situations where the relationship between the two parties is severally strained or when there is no ongoing relationship to maintain (Ikoro \& Ukonu, 2016). This suggests that the resolution of conflict through non- adversarial approach can be effective during the early stage of conflict resolution. The manner in which conflict is handled determines whether it will result to constructive or destructive outcome (Deutsch \& Coleman 2000).

Regardless of the level of conflict, there are different approaches to dealing with the incompatibilities. Conflict can result in destructive or creative ones depending on the approach that is taken. If creatively managed, it could lead to new solutions that are mutually satisfactory to both parties. Given its interdependence, Fisher (2000) identified three general strategies parties to a conflict could take in dealing with their incompatibility: win-lose, lose-lose and win-win. The win-lose approach is the most common approach to conflict resolution. The assumption here is that what one party gains, the other loses. The strategy is thus to force the other party to capitulate. Sometimes this is done through socially acceptable mechanism such as majority vote, the authority of the leader or determination of a judge. Sometimes it involves secret strategies such as threat and promise of reward. This approach is noted to always result to emergency of victorious and vanquish party between the two conflicting groups and could not provide a lasting solution to conflict. Lose-Lose approach is when neither of the parties gain what they compete for. The parties my decided these on their own or force to by external force.

Another approach is the win-win approach; this emphasizes a strategy to conflict resolution in which each party secures some of its interests from contending issues. This may come as a result of dialogue by the disputing parties with external forces playing a mediating role. Similarly, conflict resolution according to Njoku (2017) can take two different shapes: the use of force; that is forcing parties to fall into compromise line or the naked demonstration of power by one group over another. However this approach has been proved inadequate in 
resolving conflict; it leads to bottled-up anger that will erupt at any slightest opportunity. On the other hand resolution that comes about through common permission is more lasting because of the parties involved believe they are party to the resolution process and therefore willing to make it work, this approach emphasizes the power of round table negotiation in the process of conflict resolution. However, effective communication has also been shown by research and experience to be at the centre of effective crisis management. Register (2004) states that the best antidotes, in the end, are consistent and persistent communication-day in, day out, year in, year out. With consistent communication and thoughtful planning, companies are prepared to encounter crisis with a measure of calm and emerge with a measure of success

\section{Communication and Conflict Resolution}

There is no doubt that communication can play a vital role in conflict resolution or management. This is because through communication people or conflicting parties get to relate and understand one another better while absence of effective communication results to conflict. Take for instance the Biblical story of Tower of Babel construction in Genesis Chapter 11, in which the builders were making progress until there was a breakdown in communication among them which inhibited the realization of the project. Whenever there is feud between neighbours; quarrel between couples or lovers; war between nations or states, the predictable remedy prescribed by the voices of reason is communication. The prevailing view is that, faced with conflict, communicating is always the right thing to do. No wonder the U.N. Security Council encourages hostile countries to hold talks and marriage counselors advise quarrelling couples to always voice out their feelings. This indicates that prescription otherwise seems anomalous. The positive role of communication in ameliorating conflict seems so obvious that the premise is seldom give serious examination Gyamfi (2009). The questions now are: what is communication? Why should communicating be so helpful in conflict resolution? Under what conditions does communication reduce conflict?

The concept of communication is an important focus for all of human endeavors in fields as diverse as cell biology, computer science, ethnology, linguistics, sociology, anthropology, philosophy, semiotics and literary theory, Human Relations, Mathematics, each of which employs the term in its unique way. Common to all conceptualization of communication is the idea of information transfer. This implies that Information that originates in one part of a system is formulated into a message that is transmitted to another part of a system through a medium. As a result, information residing in one locus gets to another. This suggests that communication between conflicting parties could lead to information gain thus more knowledge on the contending issues. There must be an interaction for two people to play football; teach and learn, or even to engage in war. To succeed, two persons, groups, have to co-ordinate both the content and process of what they are doing. Considerable research has shown that the absence of feedback makes communication significantly more difficult (Krauss, 1987).

Effective communication requires that listeners be responsive. One of the principles of communication is to be an active listener. This recommendation seems to solicit conflicting parties in an unresolved conflict to behave co-operatively, but this is not always the case. Communication (including information and education) can be defined as diverse; covering a range from the simplest conversation between two people to the most sophisticated mass medium (Wesseler and Brinkman, 2002). In early theoretical models of communication from the 60's, communication was simply seen as a process that involves the exchange of messages from a sender to a receiver with a lot of importance given to the sender and the channel used for the transmission. Since the 70's, this model has undergone a 180 degree shift, with more emphasis given to the communication process itself; understood primarily as exchange of meanings and of the social relationships that are derived from such exchanges.

Currently, communication is considered as a social process designed to bring together actors in a two-way process. Viewed this way, the parties involved in a communication process are both senders and receivers of information and co-creators of knowledge. Communication involves bringing the sender and receiver into a consensus through negotiation and dialogue, the result of which is a shared knowledge for the right action Servaes and Malikhao (2007). The decision that are taken subsequent to sharing knowledge is often taken based on the interests, needs, and strength of the parties concerned and is always coordinated and responsive to such interest and situation of either the sender or receiver.

According to Richardson (2003), two-way communication has been used to coordinate participation in times of conflict situations. Parties involved in conflict are able to negotiate and arrive at a decision to be communicated further. It is therefore reasonable to point out that stakeholders have to communicate, negotiate and arrive at a 
decision that can be further communicated. Good communicative skills and techniques are obvious good tools in conflict resolution through dialogue and mediation. Experience has shown that conflicts are mostly caused by breakdown in communication among parties. Obviously, parties to a conflict normally have something at stake and for it to be resolved, tension must be reduced. There must be some level of mastery of knowledge which can only come through communication.

\section{Aguleri-Odeke Kogi feud over ownership of Anambra Basin crude oil: A historical overview}

Aguleri, a community in Anambra East and West local governments of Anambra state, shares common boundary with Odeke, and Echeno communities in Ibaji local Government Area of Kogi State, and Igga community of Uzo-uwani Local Government Area of Enugu State. History has it that these communities have existed as fishermen and farmers in their respective present swampy forest settlement from historic times. These communities, as expected, interact with one another in many ways. They inter marry and share other sociocultural symbols. These intercommunity relationships come with different communal clashes, as these communities are engaged in one conflict or the other with each always at the fore front of settling the disagreements through dialogue, threats and even bloody war (Daily Trust, 2014).

However, the history of Aguleri-Odeke Crude Oil Ownership Feud can be traced to Orient Petroleum Company's report around 2001. Following the pronouncement, each of the mentioned communities within the basin laid claims over the Anambra River Basin and the crude oil found beneath. Igga community of Enugu state had been reported to have instituted litigation against Aguleri community of Anambra state over the basin and lost the case as the then court ruling went in favour of Aguleri community (Daily Post, 2014). Similarly, Ibaji Local government of Kogi State was reported to have in the past brought a law suit against Enugu-Otu Aguleri over the ownership of some portion of land in Anambra River Basin and lost the case also.

However in recent times, the conflict between Aguleri and Odeke community of Anambra and Kogi states respectively has escalated and taken a different dimension, signaling war. Although it appears to be boundary dispute issue, the immediate cause could be traced to the pronouncement of Orient Petroleum Company in 2001 that it has discovered crude oil in commercial quantity in Anambra River Basin area and subsequent naming of Anambra State as oil producing state by the then president of Nigeria Dr Goodluck Jonathan in 2012. Consequently, armed conflict erupted in the area. This unresolved crisis' otherwise known as "Aguleri-Odeke feud" or "War Over Crude Oil" has led to the death and displacement of many people from these communities; destruction of property; destruction of farm lands and the activities of oil drilling is not going on smoothly as expected (Daily trust 2014).

History and comments by stakeholders from both communities show that main factors that account for the conflict are:

1 The Odeke and Aguleri communities of Kogi and Anambra state as well as Uzo-uwani in Enugu state are claim that they are exclusive owners of the oil in the disputed area. This has led to mutual suspicion.

2 The management team of the oil exploration company that is involved in oil drilling in the area are from Anambra state, and this lead to the erroneous belief that the oil belongs to Anambra state alone.

3 Another cause of the feud is the claim that Anambra state has invested 4 billion into the exploration of Ibaji oil. Whereas the true position is that the investment is by Orient Petroleum, a private company which is not the same as Anambra state and cannot make Anambra the owner of oil in Ibaji.

4 Another cause of the conflict could be Orient's inability to state clearly the areas of inclusion and exclusion of their current activity in the Anambra Basin areas.

Since conflict is preventable and transformable through application of effective communication strategies, anchored on dialogue and negotiation, it expected that the stakeholders in the various communities should resolve this age-long conflict.

\section{Communications Of The Stakeholders From Aguleri And Odeke Extraction On Ownership Of Anambra River Basin Oil: An Analysis}

Reports and presentations have shown that parties from both communities have their own reason for the disagreement. Below is direct quotation from the speeches and actions of some stakeholders from both sides of the conflict as they go about seeking ways out of the conflict. 
The former chairman of Ibaji Local Government Area, Hon Dave Ogwu, was reported to have said in his address to his follow Ibaji citizens that "during the exploration activities which includes among other things like cutting of trees, shot hole drilling and exploration wells.... compensation were paid to the people of Odeke, Echeno Ihile in Ibaji local Government Area of Kogi, state for damages caused on their land, economic trees fish ponds and shrines in the area, this is a mark of ownership of the land and we must do everything possible to reclaim our land from Anambra people"

On the other hand Idigo II representing the views and position of Aguleri was quoted by a press conference report to have stated that "the disputed land is clearly identified in the map of Nigeria as Eastern Forest Reserve in old Anambra state which is currently in the present Anambra state thus [it]belong[s] to our people.... Both Igga and Ibaji communities of Enugu and Kogi has[sic] in past instituted legitimations against us over the disputed forest and each lost out in the case....we were declared winner that shows the forest belong to the Anambra state.... we are people of justice and cannot allow anybody to trasspass our land or claim our inheritance without fighting back".

Hon. Hussan of Kogi and Hon. Uche Ekwunife, both of Nigeria's House of Representatives were reported to have clashed on the floor of the Nigerian House of Representatives in Abuja, while the former was moving motion for the Nigerian Federal Government to stop Anambra people from killing Kogi people in Anambra River Basin Area.

Also Senator Alfa recent promise to his senatorial district that he must do all things humanly possible to ensure his state was included as an oil producing state and further call on the federal government at the Senate chamber to name Kogi Oil producing state, shows that critical stakeholders in both states are not employing diplomacy in their bid to end the feud.

Poor communication hurt feelings; causes anger, frustration, and tend to erode relationships, sometimes to the point where the relationship is not fixable. Many times we call these situations personality conflicts, when in fact they are a result of poor communication. This poor communication skill appears to hold court from both sides in the Aguleri- Odeke Kogi feud. When respectable stakeholders like Hon Dave Ogwu, Hon Hussan are observed in the reports above to have used language capable of escalating the issues at hand in their respective address to their community members. The presentations of these stakeholders suggest that instead of canvassing for dialogue and negotiation, they express their readiness to use violence in pursuing their various interests.

Another institution pressed into service, apart from the state and local traditional institutions, which also accounts for the escalation of the conflict, in the conflict zone of Anambra and Kogi, is the media. The role of the media, conventional and new media, in Nigeria under democratic rule is noteworthy. There has been a significant progress in media proliferation and diversification due to the relative freedom afforded to the media in the country. This transformation has given the citizen the media for self-expression. However, the conduct of the media in the country has attracted many criticisms over the years due to polarization of the media houses, inauthentic publications, inaccurate reporting and other misconduct. This is also noticeable in the report of Aguleri-Odeke feud in which the media, depending on the owners and reporters ethnicity, reports one sided account of the cause and positions of the communities engaged in a feud.

The blame-game between the parties involved in conflict, based on the publications were further deepened by the media; by regular publishing of letters/articles; organizing press conferences of interest groups from the communities like the one from Odeke Progressive Union, Idigo dynasty, in the attempt to frame the other as contemptuous of peace, law and order. These are seen as contradictory publications by the media which according to Gyamfi (2009) escalates conflict instead of resolving it. This in no small measure is capable of fueling the Aguleri-Odeke crises instead of mitigating it. Negative body languages and presentations of the stakeholders in Aguleri-Odeke Kogi in both communities and media reportage and framing which are in the domain of poor communication are observed to be the major factors that escalate the feud around Anambra Basin oil ownership in recent times.

\section{Conclusion}

Despite much litigation by different communities in Anambra River Basin to determine the real owner or boundaries and as well end conflict in the area, it is rather becoming endemic with each community or state groaning under acrimonious conflict without an alternative commitment to resolve it. This paper concludes that the chief cause of conflict escalation is poor communication. Therefore, community leaders and other relevant stakeholders are advised to take necessary measure to prevent it or to embark on effective communication 
strategies anchored on dialogue and negotiation so as to identify and understand the actual interest, position and needs of both sides before proffering solution. In the case of the already developed conflict in the Anambra Basin, the Nigeria boundary commission (NBC) should embark on a wide research and consultations in the area so as to come up with communication interventions which would see parties involved in the Aguleri-Kogi feud agree on any settlement regarding ownership of the oil rich sections of the Anambra River Basin.

\section{References}

Adejimola .A.S. (2009) Language and communication in conflict resolution, journal of law and conflict resolution vol (1) page 001-009 retrieved from http://www.academicjournaks.org/jlcr.

Amodio, F. \& M. Di Maio (2017). Making Do with What You Have: Conflict, Input Misallocation, and Firm Performance. The Economic Journal.

Aslam.R. (2014) The Role of The Media in Conflict: Integrating Peace Journalism in the Journalism Curriculum, retrived from aut.researchgateway.ac.nz $>$ AslamR

Brahm, E. (2003). Conflict Stages. In Burgess \& H. Burgess (Eds). Beyond intractability. Retrieved at: http://www.beyondintractability.org/bi-essay/conflictstages; accessed June 29, 2019.

Burgers, H. and Guy, B. (2007). "Encyclopedia of conflict resolution”, California ABC Chio Inc. P. 434.

Coser, L.A (1986). "The function of social contract", Glencoes III: the free press. P. 5

Daily Trust (2014) The oil is ours "Kogi battles Anambra over ownership of oil we retrieved from www.dailypost.ng

Deutsch, M. \& Coleman, P. (2000). The handbook of conflict resolution: Theory and practice (eds.) San Francisco: Jossey-Bass.

Fink, C.F. (1968). Some conceptual difficulties in the theory of social conflict. Center for research in conflict resolution, University of Michigan.

Fisher, S., Ibrahim, D., Jawed Ludin, A., Smith, R., Williams, S., \& Williams, S. (2000). Working with conflict: Skills and strategies for action. London: Zed Books.

Food And Agriculture (FAO) Global report on food crises 2018. Retrieved from: http://www.fao.org/resilience/resources/resources-detail/en/c/1107313/, June 30, 2019.

Gabriela H. (2010) Communication and conflict management in local public:Towards the rhetoric of integrative communication for sustainability in Nigeria's oil and gas industry, economic insights-trade and challenges Vol (52) pg 15-23.

Gyamfi P.A. (2009) The role of communication in conflict management in Ghana: a case study in Ejura sekyedumas district in the Ashanti Region of Ghana.

Hilk,J. (2005) Conflict barometer 2005. Crisis, wars, coups d'état, negotiations, mediations, peace settlements, Heidelberg (Ed). Retrieved from http://www.rzuser.uniheidelberg.de/ lscheith/CoBa05.pdf. June 30, 2019.

Ikoro 1 \& ukonu (2016) Analysis of conflict resolution methods adopted in managing conflicts in Niger delta region of Nigeria, Hard International journal of Economic and Business Management ISSN2489-0065 Vol. 2 No 6, retrieved from www.iiardpub.org,

Krauss, R. M. (1987). The role of the listener: Addressee influences on message formulation. Journal of Language and Social Psychology, 6, 81-97.

Laue, James, and Gerald Cormick. "The Ethics of Intervention in Community Disputes.” In The Ethics of Social Intervention, edited by Gorden Bermant, Herbert Kelman and Donald Warwick. New York: Halsted Press, 1978, 205-232.

Lynch, J. \& Galtung, J. (2000). Reporting Conflict: New directions in peace journalism. Australia: University of Queensland Press.

Mack, R.W. \& Snyder, R.C. (1957) The analysis of social conflict - Toward an overview and synthesis. Journal of Conflict Resolution, 1, 212-248.

Mogekwu, M. (2011). Conflict reporting and peace journalism: In search of a new model: Lessons from the Nigerian Niger Delta Crisis. In I.S. Shaw, J. Lynch, \& R. A. Hackett (Eds), Expanding peace Journalism: Comparative and critical approaches, p239-260. Sydney: Sydney University Press. 
Njoku, I.A. (2017) The Role of Communication in Conflict Resolution, Interdisciplinary Journal of Communication Studies do1: 113-1-22 5-1-10-2017073.

Park, R.E. and Burgress, E.W. (1971) “Introduction to the science of sociology”, Chicago: University of Chicago Press. P. 137.

Register, M. (2004). "Crisis management, what to do when the unthinkable happens", London: Business Books Limited P. 6

Richardson, C., 2003. Armed Conflict Database, International Institute for Strategic Studies, London.

Servaes, J. \& Malikhao, P. 2007. Communication and sustainable development. Selected papers from the 9th UN roundtable on communication for development. FAO.

Wesseler, G. \& Brinkman, W., (2002). Bridging information gaps between farmers, policy makers, researchers and development agents. Retrieved from http://edepot.wur.nl/149057, June 30, 2019. 